\title{
Commented glossary for rheumatic spinal diseases, based on pathology
}

\author{
Robert J François, Frits Eulderink, Eric G L Bywaters
}

\begin{abstract}
Objectives-To redefine and comment on terms on a pathological basis, in order to avoid the confusion due to the use of terms with different meanings, to standardise usage among clinicians, radiologists and pathologists, and to facilitate literature searches.

Methods-Within the Committee of Pathology of the European League against Rheumatism, a study group was set up to analyse the medical literature and common practice concerning the nomenclature of rheumatic spinal diseases. The group tried to amalgamate the main trends in the field, to reconcile etymology, historical background, morphology, and common practice.
\end{abstract}

Results-The group warns against use of the terms 'acquired hyperostosis syndrome', '(von) Bechterew's disease', 'Kümmel's disease', 'pseudospondylolisthesis', 'rheumatoid spondylitis', 'spondylarthropathy' in the sense of spondarthritis, and 'spondylosis'. It recommends intercorporal or interapophyseal rather than intervertebral (osteo)chondrosis, zygapophyseal diverticulum rather than cyst, disc hernia rather than prolapse, spondyloarthritis rather than spondyloarthropathy, marginal rather than anterior spondylitis, and discarthrosis. It proposes 'zygarthrosis' to designate zygapophyseal osteoarthrosis. Conclusions-Knowledge of the pathological basis of diseases and an understanding of the original definitions given by those who coined new terms make it possible to avoid most of the confusion arising from improper use of spinal terms.

(Ann Rheum Dis 1995; 54: 615-625)

It is common experience that clinicians, radiologists, pathologists, and other scientists interested in spinal disease use a number of everyday terms with different meanings, which causes considerable confusion. In a recent paper, it appeared that 51 English speaking spine surgeons use 50 different terms for their four most common diagnoses. ${ }^{1}$

Dictionaries do not solve all problems, as they may differ, and may be incomplete, inaccurate, or even totally wrong. For example, spondylolysis is defined in one dictionary ${ }^{2}$ as 'ankylosis of a vertebral joint' or as 'osteoarthritis of the intervertebral disk space or the posterior facet joints' and in another ${ }^{3}$ as 'dissolution of a vertebra' or as 'a condition marked by platyspondylia, aplasia of the posterior arch, and separation of the pars interarticularis'. Thus the simplest and most common meaning, 'separation of the pars interarticularis', is not given by either of these two authoritative dictionaries.

The idea of standardising nomenclature in this field arose in 1967, at the VIth European Congress of Rheumatology in Lisbon. ${ }^{4}$ It was taken up again by the Committee on Pathology of the European League against Rheumatism (EULAR): a subgroup was appointed to define concepts, list synonyms, and recommend preferred terms. After agreement was reached on a number of items pertaining to the normal anatomy of the spine,,$^{5}$ a list of terms concerning pathological changes and diseases is now proposed.

The area of investigation is restricted to rheumatic diseases, excluding fractures, tumours, and congenital pathology. As part of the Committee on Pathology, the working group approached the problem from a morphological point of view. The Canadian Vocabulary of signs and symptoms of the musculoskeletal system ${ }^{6}$ has a different and broader scope.

\section{METHOD}

The working party had to represent the mainstreams in the field of spinal pathology. In particular, Anglo-American, French and German trends were incorporated without omitting the important contributions of other countries and languages.

The intention was to compile a glossary to be used by pathologists, radiologists, and clinicians. Many contacts were made with interested scientists outside the Committee.

The working group aimed to adhere as closely as possible to the following rules:

1) to respect the etymological sense of the terms;

2) to take account of the historical background and to remain faithful to the original definition given by the author who coined the term or made it popular;

3) to give descriptive definitions, accepting only those pathogenetic implications that are unanimously recognised;

4) to avoid using one term in more than one meaning;

5) if possible, to follow common practice.

It is realised that these rules are partly at odds with each other. 
PRESENTATION

Considering it important that people should understand the original meaning of the words they use, the authors recall the etymology (Etym) of terms before giving a definition (Def), comments (Com), synonyms (Syn), recommended nomenclature $(\mathrm{Rec})$ and, if applicable, the historical (His) source. In rare instances, a new term might be proposed (Prop). If useful, French $(F)$ and German $(D)$ translations are given. When, within a definition, a term is used that is defined separately in this list, it is marked by an asterisk $\left({ }^{\star}\right)$.

\section{THE GLOSSARY}

The list contains specific spinal terms and general concepts that are particularly important in spinal pathology.

\section{Ankylosing spondylitis}

see spondylitis ${ }^{\star}$, ankylosis ${ }^{\star}$.

\section{Ankylosis}

Etym: Ancient Greek ankylosis, crookedness. Def: Fusion of articulating bones, by dense fibrous tissue (syndesmosis), cartilage (synchondrosis) or bone (synostosis) leading to total loss of movement.

Com: The concept is widely used in the adjective 'ankylosing' as in ankylosing spondylitis` and vertebral ankylosing hyperostosis`.

\section{Baastrup's syndrome ${ }^{8}$}

Def: Painful condition due to abnormal friction between spinous processes, as a consequence of reduced lumbosacral angle and/or disc height, or of hyperlordosis.

Com: Pathological changes include bursa formation, thinning of interspinous soft tissues, cartilage lining of adjacent processes, with fibrillation, eventual eburnation, and bone sclerosis. ${ }^{9} 10$ A similar condition in the cervical spine was described clinically by Michotte ${ }^{11}$ and pathologically by Bywaters. ${ }^{12}$

see also bursitis ${ }^{\star}$.

\section{Bursitis, interspinous}

Etym: From Latin bursa, purse and the suffix -itisf.

Def: Inflammatory changes in the bursae that develop in aging people by synovialisation ${ }^{\star}$ of clefts within the interspinous space. ${ }^{9} 1213$ Com: The mechanical variety corresponds to Baastrup's syndrome`. Calcium pyrophosphate and hydroxyapatite deposits ${ }^{12}$ and rheumatoid changes in adults ${ }^{12}$ and children ${ }^{12}{ }^{14}$ can be seen.

\section{Chondrosis}

Etym: Ancient Greek chondros, cartilage and the suffix -osisł.

Def: Degeneration ${ }^{\star}$ or non-inflammatory developmental change of cartilage.

Com: In the spine, this would apply to the articular cartilage of the apophyseal joints and to the hyaline cartilage at the discovertebral interface.

\section{- Intervertebral chondrosis}

Def: Schmorl, ${ }^{15}$ considering the whole disc as (fibro)cartilage, used intervertebral chondrosis' as a synonym of disc degeneration.

Com: The three components of the intervertebral disc do share a common chondral origin, possessing collagen type II and glycosaminoglycans. However, Schmorl's definition introduces confusion, in that the same word could be used for degenerative changes of three structures: the hyaline cartilage of the disc, the whole disc, and the hyaline cartilage of the apophyseal joints. In accordance to our rule 4, we do not support Schmorl's nomenclature. People who wish to use it should refer to Schmorl when doing so. It would be more accurate to speak of discal or intercorporal (between the bodies) chondrosis instead of intervertebral chondrosis. see also osteochondrosis ${ }^{\star}$.

Prop: Intercorporal chondrosis.

Syn: Disc degeneration ${ }^{\star}$; intercorporal chondrosis.

\section{Cyst, zygapophyseal or facet joint}

see diverticulum ${ }^{\star}$, zygapophyseal.

\section{Degeneration}

Def: Change from a higher to a lower form, especially change of a cell, tissue or organ to a lower or less functionally active form.

Com: In a tissue or organ, degeneration can be accompanied by reactive processes such as inflammation and/or proliferation; in spite of this, a disease can be called degenerative when the first or main changes are degeneration. Degenerative is often opposed to inflammatory; however, it would be unwise to call every non-inflammatory and non-tumoral condition 'degenerative'.

Degenerative disc disease see disc degeneration ${ }^{\star}$.

\section{Diffuse idiopathic skeletal hyperostosis (DISH)}

see under hyperostosis ${ }^{\star}$

\section{Disc bulging}

Def: Protrusion of the whole disc, in contrast to the focal protrusion of a disc herniation.

$\dagger$-itis: Suffix to indicate the inflammatory nature of a condition.

-osis: Suffix to indicate either the non-inflammatory character of a lesion-most often a degenerative condition-or the widespread nature of a lesion, as in

chondromatosis.

In the previous century and in the early 20th century, the suffix -itis has been used for conditions that are now regarded as degenerative. For example, osteoarthritis deformans was the usual term for what we now, better, call (osteo)arthrosis. 
Diffuse bulging occurs in case of disc degeneration ${ }^{\star}$, due to loss of turgor, presence of fissures, or both.

\section{Disc degeneration \\ Def: Degeneration ${ }^{\star}$ of disc.}

Com: Structural changes include reduced water and modified proteoglycan content, decreased height, brown discolouration, fissuring and crumbling. Radiological features of pure disc degeneration are:

- reduced disc height;

- retrolisthesis ${ }^{\star}$ due to the obliquity of the articular facets, but this is only true if the cartilages of the interapophyseal joints are preserved;

- clefts at the insertion of the annulus fibrosus into the marginal ring, or to a variable extent throughout the whole disc, visible on plain radiographs by the vacuum phenomenon or on discograms;

- increased sagittal mobility, that may be seen on flexion and extension views. ${ }^{16}$

Disc degeneration is often accompanied or followed by bony changes in the vertebral body, mainly osteophytes ${ }^{\star}$ and osteosclerosis. In the presence of bone changes, the term discarthrosis ${ }^{\star}$ is pertinent. Some authors might prefer to consider disc degeneration and discarthrosis as one continuous process and use the term degenerative disc disease. ${ }^{17}$ Syn: Degenerative disc disease.

\section{Disc hernia(tion)}

Def: Localised protrusion of part of the disc beyond its normal boundaries: protrusion of nucleus pulposus and/or annulus fibrosus and/ or cartilage ${ }^{18}$ through a defect in the annulus and eventually in the perivertebral ligaments, or protrusion of disc material into the vertebral body through the basal cartilage.

Com: Disc prolapse is a less well suited term, for prolapse is used for other organs, such as rectum or uterus, to designate a displacement that occurs without defect of their wall or containing membranes.

Syn: Disc hernia into the vertebral body is called intravertebral disc hernia, Schmorl's node ${ }^{\star}$, cartilaginous node.

\section{Disc prolapse}

see under disc hernia ${ }^{\star}$.

\section{Disc resorption}

see under discarthrosis*.

\section{Discarthrosis}

Def: Structural and functional failure of the discal joint, analogous to synovial joint osteoarthrosis, combining disc degeneration* and bone changes.

Com: Starts as disc degeneration. Later changes are osteophytes ${ }^{\star}$, the more or less disappearance of discal tissue, fibrillation and chondrocyte clustering in the hyaline cartilage, disrupture of the endplate, with eventual Schmorl nodes ${ }^{\star}$, and changes in the subchondral bone (sclerosis, pseudocysts, erosions, eburnation). ${ }^{19}$

The boundary between disc degeneration ${ }^{\star}$ and discarthrosis is almost impossible to trace. The former might be used when the changes seem limited to the intervertebral disc, and the latter when bony changes are present.

In the cervical spine, the term uncodiscarthrosis is applicable, to point to the involvement of Luschka's joints between uncus and the corresponding area of the adjacent vertebral body; uncarthrosis plays an important role in eliciting symptoms because of the osteophytes reducing the intervertebral foramen.

His: The term discarthrosis was coined by de Sèze. He called the variety with advanced sclerosis and erosion of the vertebral body 'pseudopottique'. 20

Syn: - Erosive intervertebral osteochondrosis $^{\star 21}$ points to cases with less advanced destruction of the vertebral body than de Sèze's.

- Disc resorption* was coined by Crock $^{22} 23$ for the variety of disc degeneration ${ }^{\star}$ characterised by gross narrowing of a disc space with sclerosis of the adjacent vertebral bodies.

- Intervertebral osteochondrosis ${ }^{\star}$ is, according to Schmorl, ${ }^{15}$ a synonym for discarthrosis; for more accuracy, we recommend replacing intervertebral by intercorporal or discovertebral. Rec: Discarthrosis.

\section{Discitis}

Def: Infective or sterile inflammation of an intervertebral disc.

Com: The normal disc is avascular, but vessels will invade the disc after a lesion, allowing inflammation; discitis may also be the extension of a spondylitis ${ }^{\star}$. see spondylodiscitis ${ }^{\star}$

\section{Discopathy}

Etym: Ancient Greek diskos, disc and pathos, suffering.

Def: Any pathological condition of the disc.

Com: Should be replaced by a more specific term (disc degeneration, discitis, etc) whenever possible.

\section{Diverticulum, zygapophyseal}

Def: Normal zygapophyseal joints have a cranial and a caudal recess, visible at arthrography. ${ }^{24}$ Enlargement of these, especially the cranial one, leads to diverticula demonstrable by myelography, ${ }^{25}{ }^{26}$ computed tomography, ${ }^{27}{ }^{28}$ arthrography, ${ }^{29} 30$ and magnetic resonance imaging. ${ }^{31}{ }^{32}$ In late stages, they could erode the adjacent bone, being seen or suspected on plain $x$-ray films.

Com: The wall of such a diverticulum sometimes contains inclusions of calcified material ${ }^{33}$ as a consequence of deterioration of 
the facet joints; this is analogous to what happens in peripheral synovial joints.

Syn: - Synovial cyst is often used instead of diverticulum, but is less correct, in that cysts are classically closed while diverticula are connected with the organ from which they originate. ${ }^{3}$

- Ganglion, another term used in this context, is defined as metaplasia of paraarticular connective tissue leading to the formation of a cyst without synovial lining, not connected with the synovial cavity, and containing mucinous material. $^{34} 35$

\section{Enthesis}

Etym: Ancient Greek (par)enthesis, insertion.

Def: Attachment through insertion. In rheumatology, it serves mainly for attachment of tendon, ligament, fascia, or capsule into bone; it might also be used for attachment of heart valves, iris, etc.

Com: There are two histological types of enthesis, depending on the chondral or membranous origin of the bone tissue receiving the insertion: one by calcified cartilage and one by penetrating fibres (Sharpey's fibres). ${ }^{36-38}$

\section{Enthesitis}

Etym: Ancient Greek enthesis* and suffix -itis ${ }^{\star}$.

Def: inflammation of an enthesis.

\section{Enthesopathy}

Etym: Ancient Greek enthesis ${ }^{\star}$ and pathos, suffering.

Def: Any pathology of an enthesis.

Com: Enthesopathies include mainly metabolic, degenerative and inflammatory changes; enthesitis ${ }^{\star}$ should be preferred to enthesopathy if inflammatory changes are to be designated.

\section{Enthesophyte}

Etym: Ancient Greek enthesis ${ }^{\star}$ and phyton, plant, growth.

Def: Osteophyte` at an enthesis.

\section{Ganglion, intraspinal}

see under diverticulum ${ }^{\star}$.

\section{Hyperostosing disease \\ see under hyperostosis ${ }^{\star}$.}

\section{Hyperostosis}

Def: Hyperplasia of bone, by interstitial and/or external apposition.

Com: The word is used in vertebral ankylosing hyperostosis ${ }^{39}$ or diffuse idiopathic skeletal hyperostosis (DISH) ${ }^{\star 40}$ to name a condition characterised mainly but not exclusively by enthesophytes ${ }^{\star}$. In the spine, the most conspicuous changes are a prevertebral bone layer, asymmetrical enthesophytes and intervertebral bridges. The prevertebral ossification is of enthesophytic nature, ${ }^{4142}$ and sometimes starts as a ribbon-like calcification. ${ }^{43}$ Aufdermaur ${ }^{44}$ pointed to the association with Scheuermann's disease. Ossification of the posterior longitudinal ligament and of the capsule of the facet joints can occur in addition. These aspects are clinically important because of the encroachment upon the spinal canal at the cervical, ${ }^{45}{ }^{46}$ dorsal, ${ }^{47}$ or lumbar ${ }^{48}$ level.

Syn: - Vertebral ankylosing hyperostosis fails to address the extraspinal localisations. It can be retained to designate the spinal changes or even the whole condition, as Forestier himself had described the extraspinal lesions. ${ }^{49}$

- Spondylosis hyperostotica ${ }^{50}$ should be rejected because of the confusion around the term spondylosis ${ }^{\star}$ (see further).

- DISH is appropriate despite the fact that 'skeletal hyperostosis' sounds pleonastic.

- Arlet and Mazières ${ }^{52}$ coined the term hyperostosing disease, which is criticised by those who do not consider the often asymptomatic hyperostosis as a disease.

- Other terms stress the metabolic aspects, such as 'spondilopatia iperostosica dismetabolica, ${ }^{53}$ or the importance of enthesopathies, such as 'diffuse enthesopathic hyperostosis'. ${ }^{54}$

Rec: Diffuse idiopathic (skeletal) hyperostosis, vertebral ankylosing hyperostosis, hyperostosing disease.

see also under spondylosis ${ }^{\star}$ and further in the discussion.

- Acquired hyperostosis syndrome ${ }^{55}$ Def: Synonym of SAPHO ${ }^{\star}$, but including in addition, cases of psoriasis vulgaris.

Com: To be discarded, because this term might be confused with diffuse idiopathic hyperostosis ${ }^{\star}$, to which it is also applicable.

\section{- Synovitis-acne-pustulosis- hyperostosis-osteomyelitis syndrome (SAPHO) *}

Def: see synovitis-acne-pustulosis-hyperostosisosteomyelitis syndrome*.

\section{Kümmel's disease}

Def: Clinical syndrome of delayed posttraumatic vertebral collapse.

His: Between 1891 and 1928, $\mathrm{Kümmel}^{56}$ devoted several papers to a disease caused by a rather mild trauma of the spine, the pain of which abated after a few days, to reappear some months later after a pain free period. Immediately after the initial trauma, no radiological anomaly is disclosed; in the third phase, rarefaction and loss of bone tissue lead to collapse of the vertebral body and angulation of the spine.

Pathological data are available from Schmorl, ${ }^{15}$ who shows a picture of a necrotic vertebral 
body. This is probably why Resnick and Niwayama $^{57}$ define Kümmel's disease as vertebral osteonecrosis. These authors have published such a case, with an intraosseous vacuum, in their textbook. According to Maldague et $a l^{58}$ the latter sign is highly suggestive of ischaemic necrosis.

Com: No single aetiology can account for all cases of delayed post-traumatic vertebral collapse. Unrecognised fracture, particularly in osteoporotic patients, ischaemic osteonecrosis, sympathetic neurodystrophy, and tuberculosis are possible causes. Hence the term Kümmel's syndrome would be better than Kümmel's disease, but the question should be raised of the usefulness of that concept.

Rec: to be discarded.

\section{Limbus vertebra}

Etym: From Latin limbus, border or fringe.

Def: Vertebral body with unfused marginal ring, as in juvenile vertebral osteochondrosis ${ }^{\star}$.

\section{Olisthesis}

Etym: Ancient Greek olisthesis ${ }^{\star}$, slipping. Def: Slipping, displacement, as used in spondylolisthesis*.

\section{Osteitis condensans ilii}

see osteosis condensans ilii ${ }^{\star}$.

\section{Osteochondrosis}

Def: Degeneration * or non-inflammatory developmental change of both cartilage and bone.

Com: In the first sense, and from a morphological point of view, osteoarthrosis is a kind of osteochondrosis.

see intervertebral osteochondrosis ${ }^{\star}$.

The second sense is used to cover a number of heterogeneous conditions affecting the immature skeleton, ${ }^{59}$ including the discovertebral junction (juvenile vertebral osteochondrosis $\left.{ }^{\star}\right)$.

\section{- Intervertebral osteochondrosis}

Def: Term used by Schmorl ${ }^{15}$ to designate degeneration ${ }^{\star}$ of disc and vertebral endplates. Com: This denomination has been taken over by some authors in the US ${ }^{59}$ and Europe. ${ }^{21}$ As is the case for chondrosis*, the adjective intervertebral is not accurate enough; the latter is applicable to both the discovertebral and zygapophyseal joints; a better denomination would be intercorporal osteochondrosis.

Syn: Discarthrosis, intercorporal osteochondrosis.

\section{- Juvenile vertebral osteochondrosis}

Def: Postnatal developmental disorder of the discovertebral junction ${ }^{60}$ with focal irregularity or even absence of the osteocartilaginous growth zone and disorganised collagen fibres ${ }^{61}$ leading to several of the following changes: irregular endplates with Schmorl's nodes*, thinning of the intervertebral disc, wedging of the vertebral body, compensatory growth (increased anteroposterior diameter or localised lengthening), absence of bony fusion between margin and vertebral body (limbus vertebra ${ }^{\star}$ ). Com: Scheuermann ${ }^{62}$ described the involvement of the dorsal spine by this condition, with emphasis on wedging and hyperkyphosis. The lumbar localisation has been recognised by many authors.

Syn: Scheuermann's disease ${ }^{\star}$.

\section{Osteopenia}

Etym: Ancient Greeek osteon, bone and penia, poverty.

Def: Radiological concept for any reduction in bone tissue density, whatever the cause (osteoporosis ${ }^{\star}$, hyperparathyroidism, etc).

\section{Osteophyte}

Etym: Ancient Greek osteon, bone and phyton, plant (growth).

Def: Any bone outgrowth, but especially spurs around an osteoarthrotic joint.

Com: In peripheral joints, marginal osteophytes are readily distinguished from enthesophytes ${ }^{\star}$ at the insertion of tendons, ligaments, or capsule, because of the free space between the cartilage edge and the attachment of the capsule. Such free space is lacking at the discal joint; marginal osteophytes of the vertebral body develop into an insertional area and merit designation as enthesophytes.

In the spine, Macnab ${ }^{63}$ distinguished between marginal (claw) spurs and traction spurs, which are at some distance from the vertebral edge, but this distinction has been questioned.$^{64}$ Marginal osteophytes associated with a tear in the annulus fibrosus and probably secondary to some traction on the perivertebral ligaments have been described by Schmorl ${ }^{15}$ and François. ${ }^{65}$

\section{Osteoporosis}

Etym: Ancient Greek osteon, bone and porosis, porosity.

Def: Increased porosity of bone; local or general decrease of trabecular and/or cortical bone volume, as a result of aging, lack of gravitational stimulation, hormonal deficiency or excess, and other known and unknown factors leading to imbalance between formation and resorption. Bone trabeculae, although thinner and fewer, do not appear abnormal by current methods of investigation. Com: When destruction is evident, as in hyperparathyroidism, tumours or infection, osteolysis should better be used. There is no sharp demarcation between normal and reduced bone density. It is generally accepted that spinal osteoporosis is asymptomatic until the first compression fracture occurs.

\section{Osteosis condensans ilii}

Def: Triangular or oval bone sclerosis in the iliac bone adjacent to the sacroiliac joint, 
probably due to overload, particularly in pregnant women in whom relaxation of the pelvic joints is believed to be an important aetiological factor.

His: Osteitis condensans ilii $^{\star}$ was coined by Barsony and Polgar. ${ }^{66}$

Com: The lesion may also involve the sacral part of the sacroiliac joint. Pathology includes increase of trabecular and cortical bone, marrow fibrosis, and sometimes bone necrosis. The articular cartilage is retained.

\section{Parasyndesmophyte}

Def: Syndesmophyte ${ }^{\star}$ that is inserted at some distance from the margin of the vertebral body and/or extends beyond the vertebral margin. His: The term was coined by Dihlmann. ${ }^{67}$

Paravertebral ossification (in psoriasis) Def: Paravertebral and paradiscal ectopic bone seen in psoriasis and that, unlike syndesmophytes ${ }^{\star}$, remains unattached to the vertebrae.

His: This change was described by Bywaters and Dixon. ${ }^{68}$

\section{Pseudospondylolisthesis}

see under spondylolisthesis ${ }^{\star}$.

\section{Pustulotic arthro-osteitis}

Def: Locomotor changes associated with pustulosis palmoplantaris. These changes include synovitis, sternocostoclavicular hyperostosis, chronic sclerosing osteitis of other bones, sacroiliitis and spondylitis.

\section{Retrolisthesis}

Etym: Latin retro, backwards and ancient Greek olisthesis`, slipping.

Def: Dorsal displacement of a vertebra in relation to its distal fellow.

Syn: Retrospondylolisthesis ${ }^{3}$ is more accurate when used alone; retrolisthesis is accurate enough when used with specification of the involved vertebra.

\section{Retrospondylolisthesis see retrolisthesis ${ }^{\star}$}

\section{Rheumatoid spondylitis}

see under spondylitis ${ }^{\star}$.

\section{Rugger-jersey spine}

Def: Peculiar aspect of vertebral bodies, characterised by sclerosis of both subchondral regions and eventually by atrophy of the central area, ${ }^{69}$ giving the spine a striped appearance.

Com: Rugger-jersey spine has been described in hyperparathyroidism, renal osteodystrophy, certain types of osteopetrosis, and corticosteroid induced osteoporosis.
Syn: The osteopetrotic variety is also called sandwich vertebra.

$F:$ Rachis en maillot de rugby.

\section{Sandwich vertebra}

see rugger-jersey spine ${ }^{\star}$.

\section{SAPHO}

see synovitis-acne-pustulosis-hyperostosisosteomyelitis syndrome*.

\section{Scheuermann's disease ${ }^{62}$}

Def: Juvenile vertebral osteochondrosis ${ }^{\star}$ of the dorsal spine.

Com: see under osteochondrosis.

\section{Schmorl's node ${ }^{70}$}

Def: Cartilaginous node within the vertebral body, in continuity with the intervertebral disc and associated with an endplate lesion.

Com: Can be considered as an intravertebral disc hernia ${ }^{\star}$ through a defect or weak place in the endplate of the vertebral body or in the subchondral bone; in juvenile vertebral osteochondrosis ${ }^{\star}$, it could merely arise from irregular growth of the endplate also. The frequency of Schmorl nodes does not increase with age. ${ }^{71}$ In the T10-L1 area, Schmorl's nodes bear a relationship to disc degeneration ${ }^{\star} .{ }^{71}$

Syn: Cartilaginous node, endplate lesion, intravertebral disc hernia.

$D$ : Schmorlsches Knötchen, Knorpelknötchen. $F$ : Hernie intraspongieuse, hernie intrasomatique/intracorporéale.

\section{Spinal rheumatoid arthritis}

Def: Spinal changes due to rheumatoid arthritis.

His: The histopathology of such changes was analysed in the cervical spine, ${ }^{12}{ }^{13} 72-75$ in the dorsal spine, where the lesions extend from the costovertebral joints ${ }^{76}$ and in the lumbar spine. ${ }^{13} 73$

Syn: Rheumatoid spondylitis ${ }^{\star},{ }^{74}$ but this should be avoided because the same term has been used previously in the USA for many years, as a synonym of ankylosing spondylitis*.

\section{Spondarthritis}

Etym: Conflation of spondylarthritis* and peripheral arthritis, to point to the association of axial and peripheral involvement.

Def: Any one of a group of inflammatory diseases, comprising ankylosing spondylitis ${ }^{\star}$, Reiter's disease, reactive arthritis, psoriatic arthritis and spondylitis, arthritis with ulcerative colitis and Crohn's disease, uveitis, HLA-B27 linked peripheral arthritis, and maybe other conditions.

His: The term was coined by the Leeds group. ${ }^{77}$

Com: The spondarthritides are characterised by axial and peripheral arthritis, absence of 
rheumatoid factor, increased frequency of HLA-B27, overlapping syndromes, familial aggregation, and mutual association within patients and families. Some authors have advocated inclusion also of Whipple's disease, Behçet's disease, and other diseases, but this should be discouraged for conditions that lack the connection with HLA-B27 and do not exhibit the same inflammatory changes.

Syn: Spondyloarthropathy. The use of the radical spondylo- makes it clear that spondyloarthropathy is a composed word referring both to the spine and to another arthropathy; however, arthropathy is too vague and does not indicate the inflammatory nature of the condition; it applies to any disease involving both the spine and the limbs, such as polyarthrosis, chondrocalcinosis, ochronosis, diffuse idiopathic hyperostosis, etc. Spondyloarthritis is more accurate. Spondylarthropathy * is also used, but should be avoided, because it has another etymological significance.

Rec: Spondyloarthritis, spondarthritis.

\section{Spondylarthritis}

Etym: Ancient Greek spondylos, vertebra, arthron, article or joint and suffix -itis.

Def: Inflammation of spinal joint or joints.

- Ankylosing spondylarthritis

Def: Synonym of ankylosing spondylitis ${ }^{\star}$.

\section{Spondylarthropathy}

Etym: Ancient Greek spondylos, vertebra, arthron, article or joint, pathos, suffering.

Def: Any pathology of vertebral joints.

Com: Is also used, incorrectly, for spondarthritis* .

\section{Spondylarthrosis}

Etym: Ancient Greek spondylos, vertebra, arthron, article or joint and the suffix -osis.

Def: Osteoarthrosis of spinal joints. Specify zygapophyseal or discal.

Com: Originally, this term was used only for interapophyseal joints. The similarity between the structural and functional failure of apophyseal and discal joints and the relationship between both lend support to a common denomination. Moreover, in the very advanced stage of disc failure, the whole nucleus pulposus and most of the central part of the annulus fibrosus disappear, a cavity is formed, the basal cartilages become frayed, and eburnation can occur-all of which changes are reminiscent of diarthrodial joint arthrosis.

Syn: - Discal spondylarthrosis is called discarthrosis ${ }^{\star}$ by de Sèze; $;^{20}$ it is a very convenient and short term.

- 'Arthrose postérieure' is a widely used French synonym for zygapophyseal spondylarthrosis; it is outdated to that extent that in the anatomical nomenclature posterior is now replaced by dorsal. It would be useful to have a shorter term to replace zygapophyseal spondylarthrosis. We suggest zygarthrosis.
Prop: Zygarthrosis.

Rec: Discarthrosis, zygarthrosis.

\section{Spondylitis}

Etym: Ancient Greek spondylos, vertebra and the suffix -itis.

Def: Inflammation of a vertebra. Qualification (ankylosing, infectious, tuberculous, Salmonella, etc) is needed.

Com: Note that in 'ankylosing spondylitis', spondylitis is used in another sense than the one given here-that of inflammation of vertebral joints and eventually of the vertebra.

\section{- Ankylosing spondylitis}

Def: Inflammatory disease of the axial and to a lesser extent of the peripheral joints, with synovitis, ${ }^{78-81}$ para-articular bone sclerosis (osteitis), ${ }^{82} 83$ enthesitis ${ }^{\star},{ }^{74}$ and discitis ${ }^{\star}{ }^{13} 8384$ The inflammatory processes erode fibrocartilage, hyaline cartilage ${ }^{8083}$ and bone, leading to chondro-osseous and fibrous ankylosis, and to squaring of vertebral bodies. ${ }^{85}$ The disease almost always involves the sacroiliac joints, and is highly linked to HLA-B27.

Syn: Spondylarthritis ankylosans, ${ }^{4}$ pelvospondylitis ossificans, ${ }^{86}$ spondylitis ankylopoetica. Eponyms in this case should be avoided, especially that of von Bechterew.

His: von Bechterew (now spelled Bekhterev) created considerable confusion in describing, in $1893,{ }^{87}$ what he thought to be a genuine disease, distinct from ankylosing spondylitis; in $1899,{ }^{88}$ he published two cases of presumed ankylosing spondylitis in order to insist on the difference between this disease and his own. However, he had been preceded and would be followed by numerous authors who did describe accurately ankylosing spondylitis, as stated by different reviewers. ${ }^{89} 90$

$D$ : Ankylosierende Spondylitis.

F: Spondylarthrite ankylosante, pelvi-spondylite rhumatismale ${ }^{91}$ (better spelled pelvospondylite).

\section{- Spondylitis deformans}

Def: Obsolete synonym of spondylosis deformans ${ }^{\star}$.

\section{- Marginal (anterior) spondylitis}

Def: Inflammation of the margin of a vertebral body due to enthesitis, leading to squaring of the vertebral body, erosion, shining corners or syndesmophytes.

His: The term anterior spondylitis was introduced by Romanus and Ydén in 1952. ${ }^{86}$ Com: Since enthesitis is found all along the margin of the vertebral body, ${ }^{84}$ the adjective 'marginal' is better suited than the original 'anterior'.

Syn: Romanus lesion.

\section{- Rheumatoid spondylitis}

Def: 1. Has been used for decades in the USA as a synonym of ankylosing spondylitis ${ }^{\star}$. 
Since rheumatoid arthritis and ankylosing spondylitis are well recognised as two distinct diseases, the term has been discarded.

2. Has been used by Ball ${ }^{74}$ to describe involvement of the spine in rheumatoid arthritis. To avoid confusion, it should be replaced by spinal rheumatoid arthritis*.

\section{Spondyloarthritis \\ see spondarthritis ${ }^{\star}$.}

\section{Spondyloarthropathy see spondarthritis*.}

\section{Spondylodiscitis}

Def: Combination of spondylitis ${ }^{\star}$ and discitis*.

\section{Spondylolisthesis}

Etym: Ancient Greek spondylos, vertebra and olisthesis ${ }^{\star}$, slip.

Def: 1 . Ventral displacement of the vertebral body due to spondylolysis ${ }^{\star}$, elongation of the pars interarticularis, or more complex defects of the neural arch.

2. Ventral displacement of a whole vertebra, secondary to zygarthrosis ${ }^{\star}$.

Syn: of 1: Isthmic spondylolisthesis.

of 2: Arthrotic spondylolisthesis. In the latter sense the term pseudospondylolisthesis has been used; however, it is not well suited, as the slip is real.

\section{Spondylolysis}

Etym: Ancient Greek spondylos, vertebra and lysis, destruction.

Def: Separation of the isthmus or pars interarticularis.

Syn: Isthmolysis.

\section{Spondylosis, spondylosis deformans}

Def: 1. The term has replaced 'Spondylitis deformans', probably coined by Rokitansky in his 1844 textbook, without trying to differentiate between inflammatory and degenerative conditions. ${ }^{89} \mathrm{It}$ was used by Beneke ${ }^{92}$ and made popular by Schmorl. ${ }^{93}$ The latter author's original definition is osteophytosis ${ }^{\star}$ of the vertebral body, either the common outgrowths linked to disc degeneration ${ }^{\star}$ or those seen in association with hyperostosis ${ }^{\star}$ of the spine. Aufdermaur ${ }^{44}$ used the term as a synonym of Forestier's disease.

2. In common practice, there is no agreement on the definition. It became apparent, from a small unpublished inquiry by the authors among spine scientists that spondylosis is used by many as a synonym of spinal arthrosis (mainly of the discal joint, but for some people of the zygapophyseal joints also); for others it includes also disc degeneration without vertebral changes.

Com: 1. The adjective deformans has no sense, for most pathology induces morphological changes (that is, deformation).

2. Schmorl ${ }^{70}$ made no distinction between common osteophytes* and the osteophytes present in the case of hyperostosis $^{\star}$ of the spine. As stated previously, hyperostosis and discarthrosis $^{\star}$, despite frequent association, are better considered as separate conditions while their causes remain poorly known.

3. As so many meanings are given to the term spondylosis, without regard to the original definition, and as even the original definition confuses distinct conditions, the study group recommends avoidance of the use of the term, or that it be defined whenever it is used.

\section{- Spondylosis hyperostotica}

see under hyperostosis ${ }^{\star}$.

\section{Syndesmophyte}

Etym: Ancient Greek syn, with or together, desmos, ligament and phyton, plant or outgrowth.

Def: Bony outgrowth replacing the outer part of the annulus fibrosus, the shorter perivertebral ligament, and eventually also the deeper part of the longer perivertebral ligament, leading to an intervertebral bridge by means of complex processes involving all kinds of ossification. ${ }^{84}$

Com: When the syndesmophyte is not inserted onto the margin of the vertebral body but extends some distance beyond the vertebral margin, it may be called a parasyndesmophyte ${ }^{\star}{ }^{67}$ When the ossification remains separated from the vertebrae, as has been described in psoriasis, ${ }^{68}$ the appropriate denomination is 'paravertebral ossification'

His: This term was coined by Forestier and Robert, ${ }^{94}$ at the suggestion of Sicard, to describe the peripheral discal and paradiscal ossifications in ankylosing spondylitis.

\section{Synovialisation}

Def: Development of a synovial membrane where none was present, as within the $\operatorname{disc}^{19}$ or the interspinous space. ${ }^{10}$

Synovitis-acne-pustulosis-hyperostosisosteomyelitis syndrome (SAPHO)

Def: Group of diseases combining skin lesions (acne conglobata or fulminans, hydradenitis suppurativa, dissecting cellulitis of the scalp, pustulosis palmoplantaris) with locomotor changes (arthritis, sclerosing osteitis, sternocostoclavicular hyperostosis, recurrent chronic multifocal osteomyelitis, and eventual sacroiliitis and spondylitis). ${ }^{95} 96$

His: The acronym was coined by Chamot et al in $1987 .{ }^{95}$ 
Com: Some authors tend to consider these diseases as spondyloarthritides ${ }^{\star}$. However, the link between SAPHO conditions and HLA-B27 is weak, if it exists at all.

Pathological data are scarce; as long as morphology has not shown the identity between SAPHO and spondyloarthritis changes, it is wise to keep them separated.

\section{Vertebral ankylosing hyperostosis see under hyperostosis ${ }^{\star}$.}

\section{Zygarthrosis}

Def: Osteoarthrosis of the zygapophyseal joint. His: Coined by the present authors, as a shorter term for zygapophyseal osteoarthrosis. Com: see under spondylarthrosis ${ }^{\star}$.

\section{DISCUSSION}

Language is man's primary tool both in science and elsewhere: hence it should be kept accurate. It is not advisable to use terms in another meaning than their original or etymological sense. It is totally unsound to resort, for new concepts, to older denominations with a different meaning. Confusion in language leads to confusion in ideas and makes literature searches in data banks cumbersome.

Scientists should refrain from giving a new name to an old disease purely to give the impression of a personal discovery. Such replacement is advisable only if an earlier term is incorrect or too complicated and the new one brings more clarity or simplicity.

The study group aimed to adhere to five rules: etymology, history, morphology, clarity, common practice. As expected, these rules proved partly antagonistic.

Departure from etymology occurred three times. Ankylosis no longer means curvature, and common practice prevails when we advocate the sense of fusion of a joint. Spondylolysis does not mean dissolution of a whole vertebra, but only an interruption of the isthmus. Rheumatoid spondylitis is etymologically sound when applied to rheumatoid changes in the spine, but should be avoided, because rheumatoid spondylitis has long been used in the USA to designate ankylosing spondylitis.

Another etymological problem is related to the seronegative arthritides. When the Leeds group coined spondarthritis, we presume that they conflated 'spondylitis' and '(peripheral) arthritis' in much the same way as brunch is the conflation of breakfast and lunch. In doing so, they did not follow the usual rules of etymology..$^{97}$ The Greek radical for vertebra is 'spondyl' and is used as such when the second term of the compound name starts with a vowel. When the second term starts with a consonant, a connective ' $o$ ' is inserted between both members. This is why spondylarthritis has no connective 'o' and spondylolysis has. If the connective ' $o$ ' is used before a vowel, the impression is given that the compound name is a real connection or association between two equal concepts: unlike spondylarthritis, spondyloarthritis does not mean arthritis of a vertebra, but association of spondylitis and (peripheral) arthritis.

It is also important to be faithful to the original definition given by an author. For example, Schmorl used 'spondylosis (deformans)' for osteophytes of the vertebral bodyirrespective of the association with hyperostosis-and believed that the osteophytes resulted from discal tears. Rheumatologists from the UK or the USA, presumably without having read the original papers of Schmorl, began to use the term spondylosis for all kinds of spinal degenerative changes, such as all stages of disc degeneration and eventually apophyseal osteoarthrosis. Hence, having deviated from its original definition, the term spondylosis should now be discarded because it is too vague and too inclusive.

The study group accepted spondylarthrosis in a broader meaning (osteoarthrosis of apopyseal and discal joints) than the original one (apophyseal osteoarthrosis). In this case, some common practice (de Sèze's 'discarthrose') prevailed, in addition to the strong analogy between peripheral osteoarthrosis and disc degeneration, particularly in the advanced stage.

DISH is a disease of mature adulthood, developing frequently in spines which are already the site of osteoarthritic changes. Many aging people exhibit some non-inflammatory enthesophytes, without reaching the fully developed stage of DISH. Because of this, there is some trend to amalgamate DISH and spinal osteoarthrosis, particularly in the German literature. ${ }^{51}$ Beneke, ${ }^{92}$ and after him Schmorl, ${ }^{93}$ termed all types of vertebral osteophytes 'spondylitis deformans', later replaced by 'spondylosis deformans', which introduced the confusion. Ott ${ }^{50}$ coined 'spondylosis hyperostotica' and Biressi and Mussa $^{41}$ reported on 'artrosi discosomatica a carattere iperostosante'. There are, however, several arguments in favour of a dual conception-among others, the existence in dogs of pure hyperostosis without associated degenerative changes in the intervertebral disc, ${ }^{98}$ and the striking difference between osteoarthrosis and hyperostosis of the same joint, for example the sacroiliac joints. ${ }^{99}$ While the controversy remains unresolved, it is wise to distinguish both conditions.

Another problem in relation to DISH is to decide if it should be called a disease, as Arlet and Mazières ${ }^{52}$ and Forestier and RotesQuerol ${ }^{39}$ have done, in contrast to Smith et al ${ }^{100}$ or Rothschild et al ${ }^{101}$ who consider it as physiological aging not giving rise to symptoms.

\section{CONCLUSION}

A great deal of confusion would disappear if scientists from the field of rheumatic spinal diseases used terms with an exact, universally accepted meaning. Morphologists are able to reach agreement in describing the underlying pathological findings in these diseases; but much remains to be done to unravel their 
aetiopathogenesis and for some, even the fundamental early changes remain unknown.

The authors thank Professor Max Aufdermaur, MD, from the Pathologisches Laboratorium, Kantonsspital, Luzern, Switzerland for reading the manuscript and helping with the German medical literature. They are also indebted to Professor René Lagier, MD, from the Département de Pathologie, Université Lagier, $M D$, from the Département de Pathologie, Université
de Genève, Switzerland, for many useful comments, discussions and suggestions.

Supported by the Comité de Concertation pour la Recherche Scientifique des Forces Armées Belges (project G52).

1 Fardon D, Pinkerton S, Balderston R, Garfin S, Nasca R Salib R. Terms used for diagnosis by English speaking spine surgeons. Spine 1993; 18: 274-7.

2 Landau S I, ed. International dictionary of medicine and biology. New York: J Wiley \& Sons, 1986.

3 Taylor E J, ed. Dorland's illustrated medical dictionary, 27th edn. Philadelphia: W B Saunders, 1988.

4 Bywaters E G L, Forestier J. Glossary of terminology of the spondylopathies. In: Inst Português Reumatol, eds. $V I$ Congresso Europeu de Reumatologia. Lisbon, Portugal: Inst Português Reumatol, 1967; 472-80.

5 François R J, Bywaters E G L, Aufdermaur M. Illustrated glossary for spinal anatomy. With explanations and a French and German translation. Rheumatol Int 1985; 5: $241-5$.

6 Lussier A, Dionne S. Vocabulary of signs and symptoms of the musculoskeletal system, Vol 1: Clinical findings. Ottawa, Canada: Minister of Supply and Services, 1990.

7 Lussier A, Beauregard G, Dionne S. Vocabulary of signs and symptoms of the musculoskeletal system, Vol 2: Medical imaging signs. Ottawa, Canada: Minister of Supply and imaging signs. Ott.

8 Baastrup C I. Proc. spin. lumb. und einige zwischen diesen liegende Gelenkbildungen mit pathologischen Prozessen in dieser Region. Fortschr Geb Roentgenstr 1933; 48: $430-5$.

9 Bywaters E G L. Lesions of bursae, tendons and tendon sheaths. Clin Rheum Dis 1979; 5: 883-925.

10 Bywaters E G L, Evans S. The lumbar interspinous bursae and Baastrup's syndrome: An autopsy study. Rheumatol Int 1982; 2: 87-96.

11 Michotte L. Le syndrome des épineuses. Rev Rhum Mal Osteoartic 1949; 16: 249-51.

12 Bywaters E G L. Rheumatoid and other diseases of the cervical interspinous bursae, and changes in the spinous processes. Ann Rheum Dis 1982; 41: 360-70.

13 Bywaters E G L. The pathology of the spine. In: $\mathrm{L}$ Sokoloff, ed. The joints and synovial fluid, vol 2. New York: Academic Press, 1980; 428-547.

14 Bywaters E G L. Pathology of Still's disease. In: M I V Jayson, ed. Fuvenile chronic polyarthritis. San Francisco: Academic Press, 1976; 101-17.

15 Schmorl G, Junghanns H. Die gesunde und die kranke Wirbelsäule in Röntgenbild und Klinik. Stuttgart, Germany: G Thieme, 1968; 96-7, 158-65.

16 Knutsson $F$. The instability associated with disk degeneration in the lumbar spine. Acta Radiol 1944; 25: 593.

17 Milgram J W. Radiologic and histologic pathology of nontumorous diseases of bones and joints, Vol 1. Northbrook, IL, USA: Northbrook Publishing Cy, 1990; 519-88.

18 Deucher W G, Love J G. Pathologic aspects of posterior protrusions of the intervertebral disks. Arch Pathol 1939; 27: 201-11

19 Bywaters E G L. The pathological anatomy of idiopathic low back pain. In: White A III, Gordon S L, eds. American Academy of Orthopaedic Surgeons symposium on idiopathic low back pain. St Louis: C V Mosby Cy, 1982; 144-77.

20 de Sèze S, Guerin C, Raneau-Vareille J. Les formes pseudopottiques de la discarthrose lombaire. Sem Hôp Paris 1958; 34: 2406-16.

21 Lagier R, Guelpa G, Gerster J C. Lumbar erosive intervertebral osteochondrosis. Fortschr Geb Roentgenstr intervertebral osteochondrosis.

22 Crock $\mathrm{H}$ V. A reappraisal of intervertebral disc lesions. Med f A ust 1970; 1: 983-9.

23 Crock H V. A short practice of spinal surgery, 2nd edn. Wien, Austria: Springer, 1993; 1, 48-59.

24 Dory M A. Arthrography of the lumbar facet joints. Radiology 1981; 140: 23-7.

25 Kao C C, Uihiein A, Bickel W H, Soule E H. Lumbar intraspinal extradural ganglion cyst. $\mathcal{F}$ Neurosug $1968 ; 29$ : 168-72.

26 Kao C C, Winkler S S, Turner J H. Synovial cyst of spinal facet. Case report. $\mathcal{F}$ Neurosurg $1974 ; 41$ : 372-6.

27 Hemminghytt S, Daniels D L, Williams A L, Haughton V M. Intraspinal synovial cysts: natural history and diagnosis by CT. Radiology 1982; 145: 375-6.

28 Lemish W, Apsimon T, Chakera T. Lumbar intraspinal synovial cysts. Recognition and CT diagnosis. Spine 1989; 14: 1378-83.

29 Toussaint F, Dory M, de Buisseret J-P, Malchaire G, Maquet P, François R J. Rôle des articulations interapophysaires dans les lombalgies et sciatalgies d'origine apophysaires dans les lombalgies et sciatalgies d'origine dégénérative. Apport diagnostique et thérapeutique de l'arthrographie. In: Arlet J, Fournie A, Mazières B, eds. VIe Congrès Latin

30 Bjorkengren A G, Kurz L T, Resnick D, Sartoris D J, Garfin $S$ R. Symptomatic intraspinal synovial cysts: opacification and treatment by percutaneous injection. Am $\mathcal{F}$ Roentgenol 1987; 149: 105-7.

31 Davis R, Iliya A, Roque C, Pampati $M$. The advantage of magnetic resonance imaging in diagnosis of a lumbar synovial cyst. Spine 1990; 15: 244-6

32 Yuh W T C, Drew J M, Weinstein J N, et al. Intraspinal synovial cysts. Magnetic resonance evaluation. Spine 1991; 16: 740-5.

33 Reust P, Wendling D, Lagier R, et al. Degenerative spondylolisthesis, synovial cyst of the zygapophyseal joints, and sciatic syndrome: report of two cases and review of the literature. Arthritis Rheum 1988; 31: review $288-94$.

34 Fisk G R. Bone concavity caused by a ganglion. $f$ Bone foint Surg Am 1949; 31: 220-1.

35 Brooks D M. Nerve compression by simple ganglia: A review of thirteen collected cases. $\mathcal{f}$ Bone foint Surg $\mathrm{Br}$ 1952; 34: 391-400.

36 Sharpey W, Ellis G V. General anatomy. In: Sharpey W, Ellis $G$, eds. Elements of anatomy by fones Quain, Vo

37 1. 6th edn. London: Walton and Moberly, 1856; CXX. modalità di inserzioni tendinee alle ossa nell'uomo. Ricerche su individui di varia età. $Z$ Anat Entwgesch 1937; 107: 680-705.

38 François R J. Ligament insertions into the human lumbar vertebral body. Acta Anat 1975; 91: 467-80.

39 Forestier J, Rotes-Querol J. Senile ankylosing hyperostosis of the spine. Ann Rheum Dis 1950; 9: 321-30.

40 Resnick D, Shaul S R, Robins J M. Diffuse idiopathic skeletal hyperostosis (DISH): Forestier's disease with extraspinal manifestations. Radiology 1975; 115: 513-24.

41 Biressi P C, Mussa L. Ricerche radiologiche e anatomopatologiche sull'artrosi disco-somatica a carattere iperostosante del rachide dorsale. Reumatismo 1957; 9: 1-37.

42 Van Linthoudt D, François R J. Hyperostose vertébrale ankylosante. Apport de la microradiographie et de la microscopie de fluorescence à l'étude du rachis dorsal. Rhumatologie (Aix-les-Bains) 1981; 33: 89-98.

43 Resnick D, Niwayama G. Radiographic and pathologic features of spinal involvement in diffuse idiopathic skeletal hyperostosis (DISH). Radiology 1976; 119: 559-68.

44 Aufdermaur M. Zur pathologischen Anatomie der Spondylosis deformans. Schweiz Med Wochenschr 1955; 35: 827-39.

45 Hukuda S, Shichikawa K, Mochizuki T, Ogata M. Cervical hyperostotic myelopathy and its surgical treatment. Rhumatologie (Aix-les-Bains) 1981;33: 81-8.

46 Arlet J, Pujol M, Buc A, Géraud G, Gayrard M, Latorzeff S. Rôle de l'hyperostose vertébrale dans les myélopathies cervicales. Rev Rhum Mal Osteoartic 1976; 43: 167-75.

47 Arlet J, Roulleau J, Espagno J, et al. Compression médullaire dorsale au cours de l'hyperostose vertébrale. Rev Rhum Mal Osteoartic 1978; 45: 83-7.

48 Arlet J, Abiteboul M, Mazières B, Adam P H, Boulleau J. Sténose acquise des canaux lombaires et hyperostose vertébrale. Rev Rhum Mal Osteoartic 1983; 50: 635-41.

49 Forestier J, Certonciny A, Deslou-Paoli P. Hyperostose rachidienne ankylosante. f Radiol Electrol 1956; 37: 835-8.

50 Ott V R. Über die Spondylosis hyperostotica. Schweiz Med Wochenschr 1953; 83: 790-9.

51 Mohr W. Morphologie und Pathogenese der Spondylosis hyperostotica. In: Ott V R, ed. Spondylosis hyperostotica. Stuttgart, Germany: Enke, 1982: 17-34

52 Arlet J, Mazières B. La maladie hyperostosique. Rev Méd Int 1985; 6: 553-64.

53 Giordano M. La spondilopatia iperostosica dismetabolica. Ann Reumatol 1972; 5: 3-24.

54 Lagier R, Baud C A. Diffuse enthesopathic hyperostosisAnatomical and radiological study on a macerated skeleton. ROFO Fortschr Geb Roentgenstr Nuklearmed 1978; 129: 588-97.

55 Dihlmann W, Dihlmann S W. Acquired hyperostosis syndrome: Spectrum of manifestations at the sternocostoclavicular region. Radiologic evaluation of 34 cases. Clin Rheumatol 1991; 10: 250-63.

56 Kümmell $\mathrm{H}$ sen. Der heutige Standpunkt der posttraumatischen Wirbelerkrankung ("Kümmelsche Krankheit"). tischen Wirbelerkrankung ("Kümmelsche

57 Resnick D, Niwayama G. Osteonecrosis: Diagnostic techniques, specific situations, and complications. In: Resnick D, Niwayama G, eds. Diagnosis of bone and joint disorders, Vol 5, 2nd edn. Philadelphia: W B Saunders, $1988 ; 3238-87$.

58 Maldague B E, Noël H M, Malghem JJ. The intravertebral vacuum cleft: A sign of ischemic vertebral collapse. Radiology 1978;129:23-9.

59 Resnick D. Osteochondroses. In: Resnick D, Niwayama G, eds. Diagnosis of bone and joint disorders, Vol 5, 2nd edn. Philadelphia: W B Saunders, 1988; 3288-334.

60 Aufdermaur M. Zur Pathogenese der Scheuermannschen Krankheit. Disch Med Wochenschr 1964; 89: 73-6.

61 Aufdermaur M, Spycher M. Pathogenesis of osteochondritis juvenilis Scheuermann. f Orthop Res 1986; 4: 452-7.

62 Scheuermann H. Kyphosis dorsalis juvenilis. $Z$ orthop Chir 1921; 41: 305-17.

63 Macnab I. The traction spur. An indicator of segmental instability. F Bone foint Surg Am 1971; 53: 663-70.

64 Pate D, Goobar J, Resnick D, Haghighi P, Sartoris D J, 
Radiographic-pathologic correlation. Radiology 1988; 166: 843-6.

65 François R J. Etude microradiographique et histologique de l'ostéophyte vertébral. Pathol Eur 1969; 4: 193-208.

66 Barsony T, Polgar F. Ostitis condensans ilii, ein bisher nicht beschriebenes Krankheitsbild. Fortschr Geb Roentgenstr 1928; 37: 663-9.

67 Dihlmann W. Spondylitis ankylopoetica-die Bechterewsche Krankheit. Stuttgart, Germany: G Thieme, 1968; 36.

68 Bywaters E G L, Dixon A S. Paravertebral ossification in psoriatic arthritis. Ann Rheum Dis 1965; 24: 313-31.

69 Resnick D, Niwayama G. Parathyroid disorders and renal osteodystrophy. In: Resnick D, Niwayama G, eds. Diagnosis of bone and joint disorders, Vol 4, 2nd edn. Diagnosis of bone and joint disorders, Vol 4,

$70 \mathrm{Schmorl} \mathrm{G}$. Über die an den Wirbelbandscheiben vorkommenden Ausdehnungs- und Zerreissungsvorgänge und die dadurch an ihnen und der Wirbelspongiosa hervorgerufenen Veränderungen. Centralbl Allg Pathol Patholog Anat 1927; 40(suppl): 250-62.

71 Hilton R C, Ball J, Benn R T. Vertebral end-plate lesions (Schmorl's nodes) in the dorsolumbar spine. Ann Rheum Dis 1976; 35: 127-32.

72 Aufdermaur M. Bandscheibenbefunde der Wirbelsäule beim chronischen Gelenkrheumatismus. Schweiz Z Allgem Pathol Bakt 1957; 20: 684-9.

73 Aufdermaur M. Skelettbefunde bei primär-chronischer Polyarthritis. Dtsch Med Wochenschr 1965; 90: 1845-7.

74 Ball J. Enthesopathy of rheumatoid and ankylosing spondylitis. Ann Rheum Dis 1971; 30: 213-23.

75 Eulderink F, Meijers K A E. Pathology of the cervical spine in rheumatoid arthritis: a controlled study of 44 spines. Neth ₹ Pathol 1976; 120: 91-108.

76 Bywaters E G L. Thoracic intervertebral discitis in rheumatoid arthritis due to costovertebral joint involvement. Rheumatol Int 1981; 1: 83-97.

77 Moll J M H, Haslock I, MacRae I, Wright V. Associations between ankylosing spondylitis, psoriatic arthritis, Reiter's disease, the intestinal arthropathies, and Behcet's syndrome. Medicine (Baltimore) 1974; 53: 343-64.

78 Sivén V O. Zur Kenntnis der sogenannten chronisch ankylosirenden Entzündung der Wirbelsäule. $Z$ Klin Med ankylosirenden En

79 Cruickshank B. Lesions of cartilaginous joints in ankylosing spondylitis. I Pathol Bacteriol 1956; 71: 73-84.

80 Bywaters E G L. Pathological specificity of ankylosing spondylitis: Is it yet established? In: Ziff $M$, Cohen $P$ B, eds. Advances in inflammation research, Vol 9: The spondyloarthropathies. New York: Raven Press, 1985; 1-13.

81 Eulderink F. Pathology of ankylosing spondylitis. In: Khan M A, ed. Ankylosing spondylitis and related spondyloarthropathies. Spine-State of the Art Revied

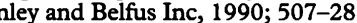

2 François R J. Le diagnostic précoce de la spondylarthrite ankylosante. Bases anatomo-radiologiques. Rhumatologie (Aix-les-Bains) 1983; 35: 121-7.
83 Bywaters E G L, Olsen E. A case of early ankylosing spondylitis with fatal secondary amyloidosis. Demon-
strated at the Royal Postgraduate Medical School. $B M F$ 1968; 2: 412-6.

84 François $\mathrm{R}$ J. Le rachis dans la spondylarthrite ankylosante. Bruxelles, Belgique: ARSCIA, 1975; 49-91.

85 Aufdermaur M. Pathogenesis of square bodies in ankylosing spondylitis. Ann Rheum Dis 1989; 48: 628-31.

86 Romanus R, Ydén S. Destructive and ossifying spondylitic changes in rheumatoid ankylosing spondylitis (Pelvospondylitis ossificans). Acta Orthop Scand 1952; 22: 88-99.

87 von Bechterew W. Steifigkeit der Wirbelsäule und ihre Verkrümmung als besondere Erkrankungsform. Neurol Centralbl 1893; 12: 426-34.

88 von Bechterew W. Über ankylosirende Entzündung der Wirbelsäule und der grossen Extremitätengelenke. Dtsch Z Nervenheilk 1899; 15: 37-44.

89 Buess H, Koelbing H M. Petite histoire de deux affections ankylosantes du rachis, la spondylarthrite et la spondylarthrose. Documenta Geigy, Acta Rheumatologica no 22. Basel, Switzerland: Geigy, 1965; 57-65.

90 Bywaters E G L. Historical introduction. In: J M H Moll ed. Ankylosing spondylitis. Edinburgh: Churchil Livingstone, $1980 ; 1-15$.

91 de Sèze S. Le vrai visage de la spondylarthrite ankylosante (pelvispondylite rheumatismale). Bull Acad Natl Méd 1958; 142: 412-21.

92 Beneke R. Zur Lehre von der Spondylitis deformans. Vers Dtsch Naturf Ärzte 1897; 69: 109-31.

$93 \mathrm{Schmorl}$ G. Beiträge zur pathologischen Anatomie der Wirbelbandscheiben und ihre Beziehungen zu den Wirbelkörpern. Arch orthop Unfall-Chir 1931; 29: $389-416$.

94 Forestier J, Robert P. Ostéophytes et syndesmophytes. Gaz Méd France (Suppl Radiol) 1934; 192-202.

95 Chamot A M, Benhamou C L, Kahn M F, Béraneck L, Kaplan G, Prost A. Le syndrome acné pustolose hyperostose ostéite (acronyme SAPHO). Résultats d'une enquête nationale. 85 observations. Rev Rhum Mal Osteoartic 1987; 54: 187-96.

$96 \mathrm{Kahn} M \mathrm{~F}, \mathrm{Ch}$ ot A M SAPHO syndrome. Rheum Dis Clin North Am 1992; 18: 225-46.

97 Daly L W. Fundamentals of medical etymology. In: Friel J P, ed. Dorland's illustrated medical dictionary, 25th edn. Philadelphia: W B Saunders, 1974; 25-40.

98 Lagier R. Spinal hyperostosis in comparative pathology. A useful approach to the concept. Skeletal Radiol 1989; 18: 99-107.

99 Brigode M, Francois R J, Dory M A. Radiological study of the sacroiliac joints in vertebral ankylosing hyperostosis. Ann Rheum Dis 1982; 41: 225-31.

100 Smith C F, Pugh D G, Polley H F. Physiologic vertebral ligamentous calcification: an aging process. $A m \mathcal{F}$ Roentgenol 1955; 74: 1049-58.

101 Rothschild B M. Diffuse idiopathic skeletal hyperostosis. Compr Ther 1988; 14: 65-9. 